\title{
PENGEMBANGAN MEDIA PEMBELAJARAN BERBASIS ROLE PLAYING GAME (RPG) MAKER XP PADA MATERI KESETIMBANGAN BENDA TEGAR UNTUK MELATIHKAN KETERAMPILAN BERPIKIR KRITIS SISWA
}

\author{
Nurhayati Ningsih ${ }^{1)}$, Prabowo'), Wahono Widodo ${ }^{3)}$ \\ ${ }^{1)}$ Mahasiswa Program Studi Pendidikan Sains, Program Pascasarjana Universitas Negeri Surabaya \\ ${ }^{2), 3)}$ Dosen Pascasarjana Prodi Pendidikan Sains Univesrtitas Negeri Surabaya \\ E-mail: nurhayatiningsih@gmail.com
}

\begin{abstract}
Abstrak: Penelitian ini bertujuan untuk mengembangkan media pembelajaran berbasis Role Playing game (RPG) Maker XP untuk melatihkan keterampilan berpikir kritis siswa. Media pembelajaran yang dikembangkan mengadaptasi model pengembangan Dick dan Carey yang dimodifikasi dengan model DDD-E. Uji coba media pembelajaran dilakukan di SMA Negeri 2 Probolinggo pada tiga kelas replikasi yaitu XI MIPA1, XI MIPA2 dan XI MIPA3 dengan menggunakan rancangan one group pretest-postest design. Teknik analisis data menggunakan analisis deskriptif kualitatif dan statistik inferensial untuk tes keterampilan berpikir kritis. Hasil penelitian menunjukkan bahwa media pembelajaran yang dikembangkan layak digunakan. Keterlaksanaan pembelajaran berkategori sangat baik. Aktivitas siswa yang menonjol adalah melakukan diskusi. Keterampilan berpikir kritis siswa mengalami peningkatan dengan nilai rata-rata gain sebesar 0,7 di kelas XI MIPA1; 0,6 di kelas XI MIPA2; dan 0,7 di kelas XI MIPA3. Hasil uji statistik, yaitu: 1) Terdapat perbedaan keterampilan berpikir kritis siswa antara kelas XI MIPA1, XI MIPA2, dan XI MIPA3, (2) Terdapat peningkatan keterampilan siswa sebelum dan sesudah pembelajaran dengan media pembelajaran yang dikembangkan, dan (3) Terdapat perbedaan peningkatan keterampilan berpikir kritis siswa anatara kelas XI MIPA1, XI MIPA2, dan XI MIPA3. Respon siswa menunjukkan sangat positif terhadap pembelajaran. Berdasarkan hasil analisis data dapat disimpulkan bahwa media pembelajaran berbasis Role Playing Game (RPG) Maker XP yang dihasilkan valid, praktis, dan efektif sehingga layak digunakan untuk melatihkan keterampilan berpikir kritis.
\end{abstract}

Kata kunci: Keterampilan Media Pembelajaran, Role Playing Game (RPG) Maker XP, Kesetimbangan Benda Tegar, Keterampilan Berpikir Kritis.

Abstract: This research aims to develope learning media-based on Role Playing Game (RPG) Maker XP to practice critical thinking skills of high school students. Learning Media developed, adapting Dicks and Careys model that modified by DDD-E model. The learning media experiment hold at SMA Negeri 2 Probolinggo in the three repliction classes, namely XI MIPA1, XI MIPA2, and XI MIPA3 by using design of one group pretest-postest design. Technical of data analyse used analyse of qualitative descriptive and inferential statistic for critical thinking skills test. The result of research showed that learning media developed, is reasonable to be used. The learning can be carried out very well. The students activities that showed prominently is to do discussion. Critical thinking skills of the students increased by an everage gain rating of 0.7 in the class XI MIPA1; 0.6 in the class XI MIPA2; and 0.7 in the class XI MIPA3. The result of statistics experiment showed that: (1) there are differences of Critical thinking skills of the students between classes of XI MIPA1, XI MIPA2, and XI MIPA3, (2) There is increasing of student skill, before and after learning by using developing learning media, and (3) there is difference of increasing Critical thinking skills of students between XI MIPA1, XI MIPA2 and XI MIPA3. The students response showed very positive to do learning. Therefore, based on the data analyse can be concluded that Learning Media based on " Role Playing Game (RPG) Maker XP" is valid, practical and effective, so it is reasonable used to practice Critical thinking skills.

Keywords: Learning Media, Role Playing Game (RPG) Maker XP, Equilibrium, Critical Thinking Skills.

\section{PENDAHULUAN}

Ilmu Fisika merupakan penunjang dalam berbagai kehidupan terutama dalam kemajuan teknologi, mulai dari teknologi yang sederhana maupun yang rumit (high way technology). Sumber manusia yang berkualitas merupakan kekuatan utama dalam mengatasi masalahmasalah yang dihadapi dalam pendidikan. 21st Century Partnership Learning Framework menyatakan bahwa
"Abad XXI Indonesia harus memiliki sumber daya yang mempunyai beberapa kompetensi, antara lain kemampuan keterampilan berpikir kritis" (BSNP, 2010). Kemampuan berpikir kritis dalam pembelajaran fisika adalah (1) memecahkan masalah yang dihadapi dalam kehidupan, (2) mengambil keputusan yang tepat, (3) sikap ilmiah dalam memecahkan masalah yang dihadapi. 
Video game merupakan salah satu bentuk permainan yang paling disukai gamer Indonesia sekarang ini yaitu game bergenre RPG (Role Playing Game). Survey menunjukkan bahwa game bergenre RPG berada di peringkat pertama dengan persentase $46 \%$, namun masih sedikit pengemban yang menjadikan game bergenre RPG sebagai game edukasi. Pengembangan video game edukasi bergenre RPG perlu dilakukan, karena video game dapat dijadikan sarana untuk meningkatkan kemampuan otak. Hal ini diperkuat oleh peneliti dari jerman yang menemukan bahwa bermain video game selama 30 menit perhari dapat memicu peningkatan di daerah tertentu di otak (Aditya, 2014).

Peneliti menggabungkan media RPG Maker XP ini dengan model kooperatif tipe STAD untuk melatihkan keterampilan berpikir kritis siswa. Vigotsky dalam Karuru (2007), pembelajaran kooperatif tipe STAD dapat membantu siswa memahami konsep-konsep fisika yang sulit serta menumbuhkan kemampuan kerjasama, kemampuan berpikir kritis dan kreatif, dan mengembangkan sikap sosial. Media RPG maker XP ini jika digabungkan dengan model kooperatif tipe STAD, pembelajaran akan terkoordinasi dengan baik karena seluruh siswa akan terkonsentrasi pada game ini, mereka akan penasaran dengan alur cerita yang ada pada game, bahkan terjadi kompetesi yang sehat antar kelompok sehingga tidak ada waktu yang terbuang. Adanya media game ini terjalin kerjasama yang baik dalam kelompok, baik yang mempunyai kemampuan rendah maupun tinggi semuanya membaur untuk memecahkan masalah yang ada dalam game, jadi RPG Maker XP ini sebagai sarana untuk membangun komunikasi yang baik sehingga tidak ada yang pasif maupun yang minder diantara mereka. Media game RPG ini sangat tepat dengan perkembangan karakteristik pada remaja khususnya SMA sebagai hiburan, oleh karena itu dengan situasi yang mendukung suasana hati para siswa maka untuk menumbuhkan dan melatihkan keterampilan berpikir kritis siswa lebih mudah jika dibandingkan dengan pembelajaran kooperatif tipe STAD tanpa game.

Materi kesetimbangan benda tegar merupakan kajian dalam ilmu fisika yang didalamnya terdapat pengetahuan konseptual, dan prosedural. Pengetahuan konseptual menyangkut keterkaitan banyak konsep, sedangkan pengetahuan prosedural berkaitan dengan tahap-tahap atau urutan pekerjaan yang harus dilakukan, dimana setiap tahap memerlukan penguasaan konsep-konsep tertentu. Pembelajaran kesetimbangan benda tegar melibatkan proses, eksperimen, pengamatan, pengolahan data, diskusi, dan menarik kesimpulan.

Berdasarkan uraian diatas, peneliti menganggap perlu mengadakan penelitian dengan judul
"Pengembangan Media Pembelajaran Berbasis Role Playing Game (RPG) Maker XP Pada Materi Kesetimbangan Benda Tegar Untuk Melatihkan Keterampilan Berpikir Kritis Siswa". Dalam penelitian ini akan dikembangkan media pembelajaran berbasis Role Playing Game (RPG) Maker XP untuk melatihkan keterampilan kritis, kemudian diimplementasikan.

Ennis (1996) menyatakan bahwa secara umum kriteria seseorang berpikir kritis adalah FRISCO (focus, reason, inference, situation, clarity, and overview).

1. F (focus) dalam membuat sebuah keputusan tentang apa yang diyakini maka harus bisa memperjelas pertanyaan atau isu yang tersedia.

2. R (reason): mengetahui alasan-alasan yang mendukung atau bertentangan dengan putusanputusan yang dibuat berdasarkan situasi dan fakta yang relevan.

3. I (inference): penarikan kesimpulan yang benar berdasarkan langkah-langkah dari alasan-alasan ke kesimpulan yang masuk akal.

4. S (situation): memahami dan selalu menjaga situasi dalam berpikir akan membantu memperjelas pertanyaan dan mengetahui arti istilah-istilah kunci serta bagian-bagian yang relevan sebagai pendukung.

5. C (clarity): menjelaskan arti atau istilah-istilah yang digunakan dalam berpendapat.

6. O (overview): meninjau kembali dan meneliti secara menyeluruh keputusan yang diambil.

RPG Maker XP merupakan sebuah perangkat lunak yang digunakan untuk membuat game berbasis RPG. RPG (Role Playing Game) adalah sebuah permainan dimana player dapat mengontrol satu karakter, yaitu karakter utama dalam suatu cerita yang dimainkan. Sebagai karakter utama, player bisa menjelajah, berinteraksi dan berperan penuh dalam cerita tersebut. Game RPG dimainkan seperti sebuah drama sehingga membuat peserta didik penasaran akan akhir dari cerita tersebut. RPG maker XP yang merupakan versi keempat dari beberapa versi RPG Maker. Menurut SEAMOLEC (2007), memiliki tiga tahapan dalam pembuatan game, yaitu:

\section{Mapping}

Map adalah suatu elemen yang penting dalam pembuatan game RPG. Map disebut juga dengan latar dari game. Latar harus dibuat sesuai dengan alur cerita yang sedang terjadi. Proses mapping memerlukan daya imajinasi yang tinggi dari pembuatnya.

\section{Database Using}

Database adalah kumpulan dari bermacam-macam data yang digunakan dalam game, seperti tokoh, senjata, animasi, dan suara. Proses database using data yang digunakan dalam game dapat diubah, 
dapat dikurangi dan dapat ditambah. Proses yang ada dalam game terdapat pengaturan parameterparameter untuk objek. Database yang perlu diperhatikan dalam pembuatan game ini hanya database actors, database animations, database tilesets, dan database system.

\section{Eventing}

Event merupakan arti kejadian. Event di dalam game merupakan suatu elemen penting yang membuat game terlihat lebih hidup. Maker XP dalam RPG dapat mengatur event yang berjalan ketika sesuatu terjadi. Pengaturannya, sedikit banyak mirip dengan struktur kontrol pada pemrograman. Event dapat diletakkan di map, maupun melalui common Event yang ada di database. Common Event berisi perintah untuk melakukan event. Proses pemberian perilaku pada objek yang ada dalam game disebut eventing. Perilaku itu dapat berupa dialog antar tokoh, backsound, perpindahan tokoh ke map lain.

Penelitian ini ada beberapa masalah yang akan dijawab yaitu: (1) Bagaimana validitas media yang dikembangkan? (2) Bagaimana kepraktisan media yang dikembangkan? (3) Bagaimana keefektifan media yang dikembangkan?

\section{METODE PENELITIAN}

Penelitian ini mengadaptasi dari pengembangan model Dick dan Carey (1990) yang dimodifikasi dengan model DDD-E oleh Ivers \& Baron (2002). Penelitian dilakukan pada 3 kelas replikasi yaitu: kelas XI MIPA 1, XI MIPA 2, dan XI MIPA 3 masingmasing dengan jumlah siswa sebanyak 30 siswa. Penelitian ini dilaksanakan di SMA Negeri 2 Probolinggo di kelas XI MIPA semester genap tahun pelajaran 2015/2016 pada materi kesetimbangan benda tegar. Teknik pengumpulan data menggunakan teknik validasi, observasi, tes dan penyebaran angket, sedangkan teknik analisis data menggunakan analisis statistic deskriptif.

\section{HASIL PENELITIAN DAN DISKUSI}

\section{A. Kevalidan Media Pembelajaran}

1. Tes Keterampilan berpikir kritis

Tes yang dikembangkan berupa butir soal yang digunakan untuk mengembangkan keterampilan berpikir kritis siswa. Tes yang dikembangkan berjumlah 12 soal dengan soal uraian. Berdasarkan penilaian validator terhadap komponen butir soal diperoleh skor rata-rata 3,45 artinya butir soal baik untuk digunakan sebagai alat ukur untuk mencapai keterampilan berpikir kritis. Hasil perhitungan reliabilitas didapatkan skor reliabilitas butir soal sebesar $92,11 \%$ artinya butir soal reliabel untuk dijadikan sebagai alat ukur mencapai keterampilan berpikir kritis. Tes hasil keterampilan berpikir kritis ini memiliki nilai koefisien reliabilitas dari validator yang cukup tinggi karena tes hasil belajar dikembangkan mengacu pada materi, konstruksi, dan bahasa yang sesuai dengan kaidah pengembangan butir soal.

\section{Media RPG Maker XP}

Media $R P G$ Maker XP dikembangkan untuk membantu proses pembelajaran. Media $R P G$ Maker XP ini dikembangkan agar membuat siswa tertarik terhadap konsep-konsep kesetimbangan benda tegar dan membantu siswa dalam memahami materi tersebut. Adapun penilaian terhadap media RPG Maker XP meliputi: komponen kelayakan format, kualitas ilustrasi dan game, kejelasan pencapaian konsep, komunikatif, dialogis dan interaktif, lugas, kesesuaian dengan kaidah bahasa Indonesia. Berdasarkan perhitungan diperoleh skor rata-rata yaitu 3,21 artinya media RPG Maker XP baik untuk digunakan dalam pembelajaran. Hasil perhitungan reliabilitas, skor reliabilitas media game adalah $97,67 \%$ artinya media game reliabel untuk digunakan dalam pembelajaran. Media $R P G$ Maker XP ini memiliki nilai koefisien reliabilitas dari validator yang cukup tinggi karena media yang dikembangkan memenuhi aspek yang mengacu pada Dick dan Carey yang dimodifikasi dengan DDD-E.

\section{B. Kepraktisan Media Pembelajaran}

1. Keterlaksanaan Pembelajaran

Pengamatan keterlaksanaan pembelajaran dengan media $R P G$ Maker XP yang berorientasi keterampilan berpikir kritis pada replikasi I, replikasi II, dan replikasi III rata-rata berkategori sangat baik.

2. Aktivitas Siswa Selama Mengikuti Pembelajaran

a. Replikasi I

Hasil pengamatan aktivitas siswa pada kelas replikasi I secara ringkas dapat dilihat pada Gambar 1.

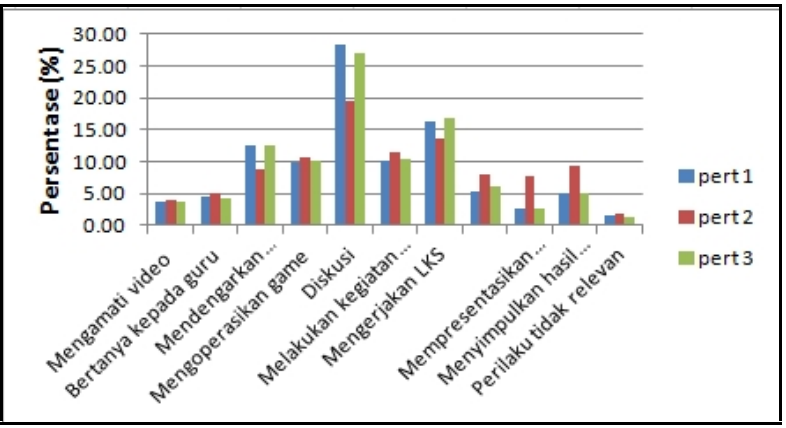

Gambar 1 Proporsi Kemunculan Aktivitas Siswa selama KBM pada Replikasi I (XI MIPA1)

Berdasarkan Gambar 1 dapat diketahui aktivitas siswa yang paling menonjol adalah melakukan diskusi yaitu $24,91 \%$, mengerjakan LKS yaitu $15,63 \%$, dan melakukan kegiatan penyelidikan sebesar $10,71 \%$. Hal ini dapat diartikan bahwa kegiatan pembelajaran berpusat pada siswa dan dalam pelaksanaan 
pembelajaran siswa terlibat aktif. Hasil analisis reliabilitas instrumen aktivitas siswa adalah 95,85\% yang menunjukkan bahwa instrumen pengamatan aktivitas siswa dalam pembelajaran dengan media $R P G$ Maker XP berkatagori baik dan dapat digunakan untuk mengukur aktivitas siswa dalam pembelajaran.

b. Replikasi II

Hasil pengamatan aktivitas siswa pada kelas replikasi II secara ringkas dapat dilihat pada Gambar 2.

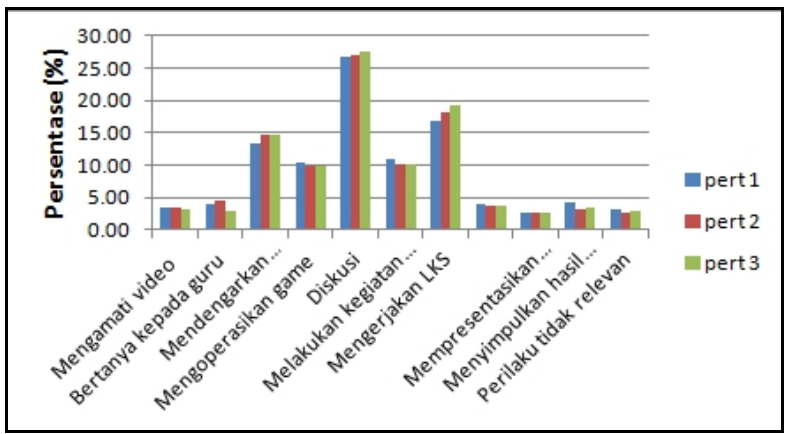

Gambar 2. Proporsi Kemunculan Aktivitas Siswa selama KBM pada Replikasi II (XI MIPA2)

Berdasarkan Gambar 2 dapat diketahui aktivitas siswa yang paling menonjol adalah melakukan diskusi yaitu $27,06 \%$, mengerjakan LKS yaitu $18,07 \%$, dan mendengarkan penjelasan sebesar $14,25 \%$. Hal ini dapat diartikan bahwa kegiatan pembelajaran masih berpusat pada siswa dan dalam pelaksanaan pembelajaran siswa terlibat cukup aktif. Hasil analisis reliabilitas instrumen aktivitas siswa adalah 98,03\% yang menunjukkan bahwa instrumen pengamatan aktivitas siswa dalam pembelajaran dengan media $R P G$ Maker XP berkatagori baik dan dapat digunakan untuk mengukur aktivitas siswa dalam pembelajaran.

\section{c. Replikasi III}

Hasil pengamatan aktivitas siswa pada kelas replikasi III secara ringkas dapat dilihat pada Gambar 3.

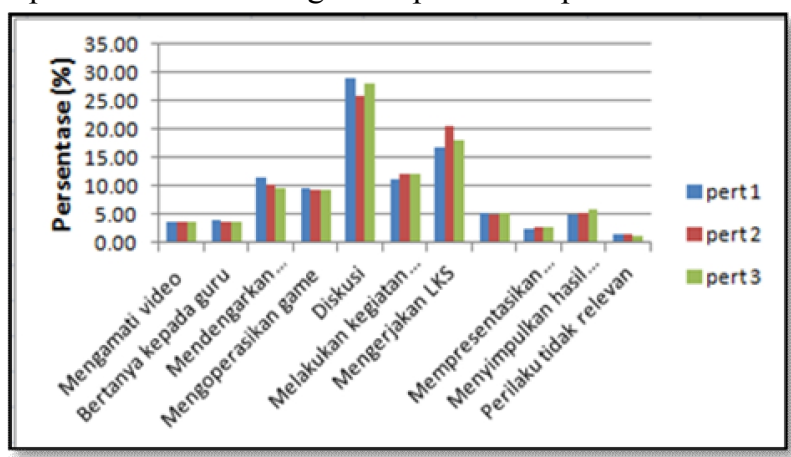

Gambar 3. Proporsi Kemunculan Aktivitas Siswa selama KBM pada Replikasi III (XI MIPA3)

Berdasarkan Gambar 3 dapat diketahui aktivitas siswa yang paling menonjol adalah melakukan diskusi yaitu $27,68 \%$, mengerjakan LKS yaitu $18,53 \%$, dan melakukan kegiatan penyelidikan $11,86 \%$. Hal ini dapat diartikan bahwa kegiatan pembelajaran berpusat pada siswa dan dalam pelaksanaan pembelajaran siswa terlibat aktif. Hasil analisis reliabilitas instrumen aktivitas siswa adalah $96,98 \%$ yang menunjukkan bahwa instrumen pengamatan aktivitas siswa dalam pembelajaran dengan media RPG Maker XP berkatagori baik dan dapat digunakan untuk mengukur aktivitas siswa dalam pembelajaran.

\section{Keefektivitas Media Pembelajaran}

1. Keterampilan Berpikir Kritis

a. Replikasi I

Berdasarkan perhitungan N-Gain didapatkan informasi bahwa rata-rata keterampilan berpikir kritis siswa berada pada kategori tinggi yaitu sebesar 0,7 , hal ini menunjukkan bahwa media pembelajaran berbasis $R P G$ Maker XP sangat berpengaruh terhadap kemampuan keterampilan berpikir kritis siswa.

Peningkatan aspek keterampilan berpikir kritis siswa, yaitu focus, reason, inference, clarity, dan overview, sebelum dan sesudah mengikuti pembelajaran dengan menggunakan media $R P G$ Maker XP pada materi kesetimbangan benda tegar ditunjukkan pada Gambar 4.

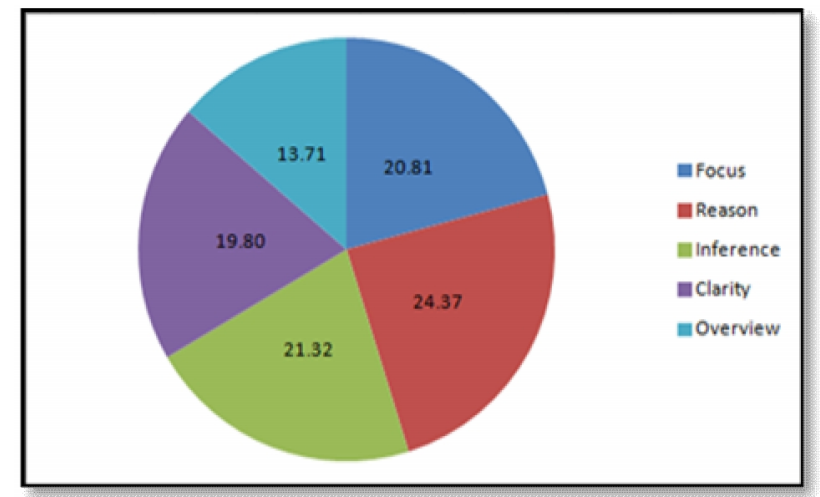

Gambar 4. Diagram Lingkaran N-Gain Peningkatan Aspek Keterampilan Berpikir Kritis Siswa Replikasi I (XI MIPA1)

Berdasarkan Gambar 4 nilai indikator berpikir kritis yang paling dominan terdapat pada reason, hal ini disebabkan karena soal dengan indikator argumen adalah soal kontekstual yang bisa dianalisis oleh siswa dan merupakan penerapan sehari-hari. Soal dengan indikator memutuskan atau memilih kemungkinan yang akan dipilih adalah soal yang persentasenya paling kecil, hal ini disebabkan karena siswa tidak terbiasa mengerjakan soal-soal tersebut sehingga siswa mengalami kesulitan dalam menjawab.

\section{b. Replikasi II}

Berdasarkan perhitungan N-Gain didapatkan informasi bahwa rata-rata keterampilan berpikir kritis siswa berada pada kategori sedang yaitu sebesar 0,6 , hal ini menunjukkan bahwa media pembelajaran berbasis RPG Maker XP berpengaruh terhadap kemampuan keterampilan berpikir kritis siswa. Peningkatan aspek keterampilan berpikir kritis siswa, yaitu focus, reason, inference, clarity, dan overview, sebelum dan sesudah mengikuti pembelajaran dengan menggunakan media 
RPG Maker XP pada materi kesetimbangan benda tegar ditunjukkan pada Gambar 5.

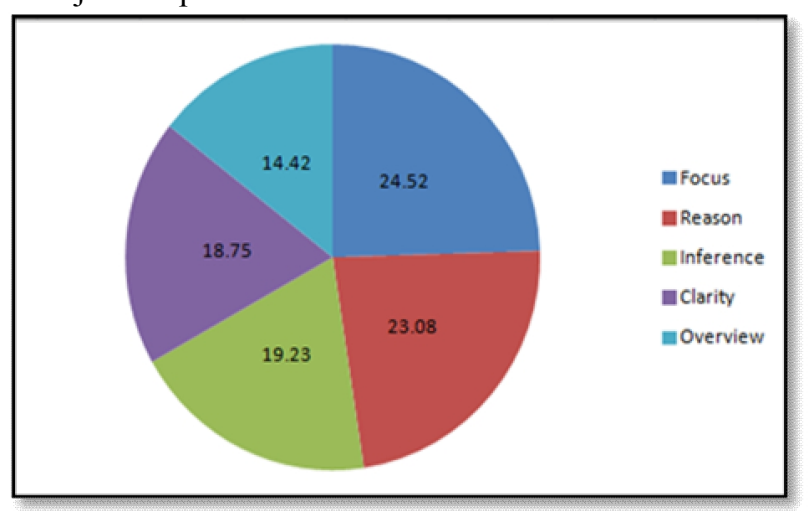

Gambar 5. Diagram Lingkaran N-Gain Peningkatan Aspek Keterampilan Berpikir Kritis Siswa Replikasi II (XI MIPA2)

Berdasarkan Gambar 5 di atas nilai indikator berpikir kritis yang paling dominan terdapat pada focus, hal ini disebabkan karena soal tersebut merupakan soal penerapan sehari-hari sehingga siswa mudah untuk merumuskan suatu permasalahan. Soal dengan indikator memutuskan atau memilih kemungkinan yang akan dipilih adalah soal yang persentasenya paling kecil, hal ini disebabkan karena siswa tidak terbiasa mengerjakan soal-soal tersebut sehingga siswa mengalami kesulitan dalam menjawab.

\section{c. Replikasi III}

Berdasarkan perhitungan N-Gain didapatkan informasi bahwa rata-rata keterampilan berpikir kritis siswa berada pada kategori tinggi yaitu sebesar 0,7 , hal ini menunjukkan bahwa media pembelajaran berbasis $R P G$ Maker XP sangat berpengaruh terhadap kemampuan keterampilan berpikir kritis siswa. Peningkatan aspek keterampilan berpikir kritis siswa, yaitu focus, reason, inference, clarity, dan overview, sebelum dan sesudah mengikuti pembelajaran dengan menggunakan media RPG Maker XP pada materi kesetimbangan benda tegar ditunjukkan pada Gambar 6.

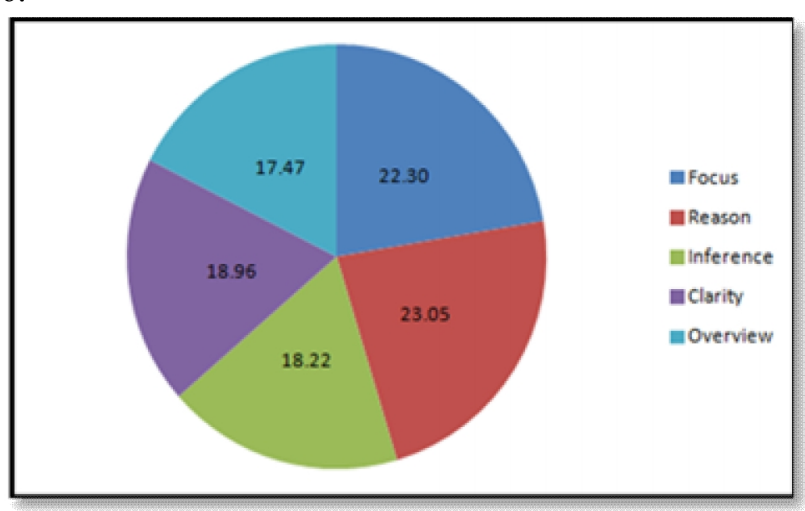

Gambar 6. Diagram Lingkaran N-Gain Peningkatan Aspek Keterampilan Berpikir Kritis Siswa Replikasi III (XI MIPA3)
Berdasarkan Gambar 4.6 di atas nilai indikator berpikir kritis yang paling dominan terdapat pada reason, hal ini disebabkan karena soal dengan indikator argumen adalah soal kontekstual yang bisa dianalisis oleh siswa dan merupakan penerapan sehari-hari. Soal dengan indikator memutuskan atau memilih kemungkinan yang akan dipilih adalah soal yang persentasenya paling kecil hal ini, disebabkan karena siswa tidak terbiasa mengerjakan soal-soal tersebut sehingga siswa mengalami kesulitan dalam menjawab.

1) Analisis t-Test

Analisis t-Test adalah untuk mengetahui apakah ada perbedaan hasil tes keterampilan berpikir kritis siswa sebelum dan sesudah mengikuti pembelajaran dengan media $R P G$ Maker XP maka dilakukan analisis t-Test. Hasil Uji t-Test replikasi I, II dan III didapatkan $t_{\text {hitung }}$ lebih besar dari $t_{\text {tabel }}$ sehingga dapat disimpulkan bahwa terdapat perbedaan signifikan antara pretest dan posttest pembelajaran melalui media RPG Maker XP untuk melatih keterampilan berpikir kritis.

2) Uji Normalitas dan Uji Homogenitas

Berdasarkan hasil uji normalitas dan homogenitas pada hasil pretest dan posttest, dan NGain tes keterampilan berpikir kritis diperoleh hasil bahwa semua data terdistribusi normal dan homogen.

3) Analisis Varians

Analisis varians bertujuan untuk menguji perbedaan N-Gain hasil tes keterampilan berpikir kritis siswa untuk tiga kelas replikasi sekaligus. Analisis yang dilakukan adalah analisis varians satu jalur (ANAVA- Satu Jalur). Berdasarkan analisis uji homogenitas varians diperoleh bahwa varians ketiga kelas data siswa adalah homogen, maka selanjutnya dapat dilakukan analisis perhitungan Anava Satu Jalur untuk membuktikan kedua hipotesis di atas. Hasil analisis varians didapatkan

$$
\text { Harga } \mathrm{F}_{0}=\frac{M K k}{M K d}=\frac{0.1305}{0,017}=7,67
$$

berdasarkan nilai dari tabel $\mathrm{F}$, ternyata $\mathrm{Ft} 5 \%$ $=3,10$ yang menunjukkan bahwa harga $F_{0}>F_{t}$, berarti dapat disimpulkan signifikan, $\mathrm{H}_{0}$ ditolak, artinya ada perbedaan yang signifikan antara kelas replikasi I, replikasi II dan replikasi III. Hal ini menunjukkan bahwa hasil keterampilan berpikir kritis paling sedikit ada dua kelas yang tidak sama.

\section{Respon Siswa}

Berdasarkan perhitungan respon siswa didapatkan informasi bahwa siswa merespon sangat positif terhadap media pembelajaran RPG Maker XP yang digunakan dalam pembelajaran untuk melatih keterampilan berpikir kritis. 


\section{PENUTUP}

A. Simpulan

Berdasarkan temuan-temuan diatas maka dapat disimpulkan bahwa pembelajaran dengan media $R P G$ Maker XP pada materi kesetimbangan benda tegar yang telah dikembangkan valid, praktis dan efektif sehingga layak digunakan untuk melatihkan keterampilan berpikir kritis.

B. Saran

Berdasarkan hasil penelitian yang telah dilakukan, maka peneliti memberikan beberapa saran sebagai berikut:

1. Media $R P G$ Maker XP ini perlu diterapkan dalam pembelajaran untuk melatihkan keterampilan berpikir kritis.

2. Media pembelajaran $R P G$ Maker XP yang dikembangkan hanya terbatas pada kesetimbangan benda tegar, untuk itu perlu dikembangkan perangkat dan media pembelajaran $R P G$ Maker $X P$ pada materi-materi lain.

3. Media pembelajaran $R P G$ Maker $X P$ yang dikembangkan masih terbatas untuk melatihkan keterampilan berpikir kritis. Padahal selain berpikir kritis tuntutan abad 21 adalah kreatifitas. Untuk itu perlu diupayakan pengembangan media yang berorientasi untuk mengembangkan kreatifitas siswa.

\section{REFERENSI}

Agell, \& Laia. (2015). Using Role Play to Debate Animal Testing. Journal of Biological Education, v49 n3 p309-321 2015
Akker, J. V. D. (1999). Principles and Methods of Development Research. Dalam Plomp, T; Nieveen, N; Gustafson, K; Branch, R.M; dan van den Akker, J (eds). Design Approaches and Tools in Education and Training. London: Kluwer Academic Publisher

Baek, \& Youngkyun. (2013). Cases on Digital Game-Based Learning: Methods, Models, and Strategies. Journal of Educational Technology \& Society, v14 n4 p181-191 2011

Bloom, B.S., (1979). Taxonomy of Educational Objectives; The Classification of

Educational Gools. Hand Book 1 Cognitive Domain . USA: Longman Inc.

Borich, G. D. (1994). Obsevation Skills for Effective Teaching. Engelwood Cliff: Macmi Lan Publishing Company

BSNP, (2010). Paradigma Pendidikan Nasional Abad XXI. Jakarta: BSNP.

Freedman, \& Young. (2002). Fisika Universitas Edisi Kesepuluh Jilid 1(terjemahan). Jakarta: Penerbit Erlangga

Graham, K. L. (2010). Virtual Playgrounds Assessing the Playfulness of Massively Multiplayer Online Role-Playing Games. American Journal of Play, v3 n1 p106-125 Sum 2010

Jasson. (2009). Role Playing Game (RPG) Maker, Software Penampung Kreativitas, Inovasi, \& Imajinasi bagi Game Designer. Yogyakarta: Andi. 